\title{
Microbial enzymes: industrial progress in 21st century
}

\author{
Rajendra Singh $^{1} \cdot$ Manoj Kumar $^{1} \cdot$ Anshumali Mittal $^{2} \cdot$ Praveen Kumar Mehta $^{3}$
}

Received: 8 April 2016/Accepted: 1 August 2016/Published online: 19 August 2016

(c) The Author(s) 2016. This article is published with open access at Springerlink.com

\begin{abstract}
Biocatalytic potential of microorganisms have been employed for centuries to produce bread, wine, vinegar and other common products without understanding the biochemical basis of their ingredients. Microbial enzymes have gained interest for their widespread uses in industries and medicine owing to their stability, catalytic activity, and ease of production and optimization than plant and animal enzymes. The use of enzymes in various industries (e.g., food, agriculture, chemicals, and pharmaceuticals) is increasing rapidly due to reduced processing time, low energy input, cost effectiveness, nontoxic and eco-friendly characteristics. Microbial enzymes are capable of degrading toxic chemical compounds of industrial and domestic wastes (phenolic compounds, nitriles, amines etc.) either via degradation or conversion. Here in this review, we highlight and discuss current technical and scientific involvement of microorganisms in enzyme production and their present status in worldwide enzyme market.
\end{abstract}

Keywords Microorganisms - Enzymes - Bioconversion · Application · Industry

Praveen Kumar Mehta

pk.mehta@tx.technion.ac.il

1 Department of Biochemistry, VP Chest Institute, University of Delhi, Delhi 110007, India

2 Mill Hill Laboratory, Division of Structural Biology and Biophysics, The Francis Crick Institute, London, UK

3 Department of Biotechnology and Food Engineering, Technion-Israel Institute of Technology, 32000 Haifa, Israel

\section{Introduction}

Microbes have been utilized since ancient human civilization with first reported commercial application of yeast to produce alcoholic beverages from barley by the Babylonians and Sumerians as early as 6000 BC. The microbial enzymes have gained recognition globally for their widespread uses in various sectors of industries, e.g., food, agriculture, chemicals, medicine, and energy. Enzyme mediated processes are rapidly gaining interest because of reduced process time, intake of low energy input, cost effective, nontoxic and eco-friendly characteristics $(\mathrm{Li}$ et al. 2012; Choi et al. 2015). Moreover, with the advent of recombinant DNA technology and protein engineering a microbe can be manipulated and cultured in large quantities to meet increased demand (Liu et al. 2013). Associated driving factors that motivate the use of microbial enzymes in industrial applications are increasing demand of consumer goods, need of cost reduction, natural resources depletion, and environmental safety (Choi et al. 2015). Global market for industrial enzymes was estimated about $\$ 4.2$ billion in 2014 and expected to develop at a compound annual growth rate (CAGR) of approximately $7 \%$ over the period from 2015 to 2020 to reach nearly $\$ 6.2$ billion ( 2015b: Industrial Enzyme Market). Enzymes are biological molecules, proteinaceous in nature with the exception of catalytic RNA molecules (ribozymes), and act as catalyst to support almost all of the chemical reactions required to sustain life (Cech and Bass 1986). Enzymes are highly specific; only accelerate the rate of particular reaction by lowering the activation energy without undergoing any permanent change in them, and therefore, are vital biomolecules that support life (Fersht 1985; Piccolino 2000; Aldridge 2013). They require typically milder condition of temperature and pressure for catalyzing reactions, 
and are used as an alternative to hazardous chemical pollutant owing to their biodegradable and nontoxic nature (Mojsov 2011; Illanes et al. 2012; Choi et al. 2015). In addition to advantages of enzymes over conventional methods, there are some drawbacks of using enzymes in healthcare and other industries. For many mammalian enzymes, $37^{\circ} \mathrm{C}$ and 7.4 are the optimal temperature and $\mathrm{pH}$, respectively, and their activity is highly sensitive to any change in these parameters. Higher temperature $\left(>40^{\circ} \mathrm{C}\right)$, and a large deviation from the physiological $\mathrm{pH}$ (7.4) lead to their denaturation, which limits the use of these macromolecules in non-physiological conditions. Additionally, they are susceptible to substrate or product inhibition and their products may cause allergic reactions. The high cost of isolation and purification of enzymes and their difficult recovery for subsequent reuse may discourage their use (Johannes et al. 2006).

Enzymes are large macromolecules composed of polymers of amino acids connected by amide bonds, ranging from kilodalton (insulin) to megadalton (ribosome) in molecular mass. Catalytic site of these macromolecules is often buried deep within hydrophobic pockets, which determines the specificity for their substrate. This specificity of enzyme to catalyze reactions between one types of chemical compound over the other provides the basis of its classification and name. With the great advancement achieved in the area of biochemistry after 1940, a large number of enzymes were isolated and characterized, and therefore, it was necessary to regulate the enzyme nomenclature. Thus, International Union of Biochemistry and Molecular Biology (IUBMB) in consultation with International Union for Pure and Applied Chemistry (IUPAC) established an Enzyme Commission (EC) to be in charge of guiding the naming and systematic classification for enzymes (Liese et al. 2006). According to the type of reaction catalyzed, the enzyme commission has classified the enzymes into six main classes, mentioned in Table 1.

Microorganisms are favored sources for industrial enzymes due to easy availability, and fast growth rate. Genetic changes using recombinant DNA technology can easily be done on microbial cells for elevated enzyme production and scientific development (Illanes et al. 2012). Production of microbial enzymes is a necessary event in the industrial sectors, due to the high and superior performances of enzymes from different microbes, which work well under a wide range of varied physical and chemical conditions. Further, microbial enzymes are used in the treatment of health disorders associated with deficiency of human enzymes caused by genetic problems (Vellard 2003; Anbu et al. 2015). For instance, patients with inherited congenital sucrase-isomaltase deficiency are unable to digest sucrose, and therefore, sacrosidase ( $\beta$-fructofuranoside fructohydrolase, EC 3.2.1.26) enzyme is given orally to facilitate digestion of sucrose (Treem et al. 1999). In addition, phenylalanine ammonia lyase (EC 4.3.1.24) is used to degrade phenylalanine in genetic phenylketonuria disorder (Sarkissian et al. 1999).

The extensive application of microbes in different bioprocess is used to deliver a variety of products in applied industries. Table 2 summarizes several applications of microorganisms to deliver a variety of products. The Schematic representation of industrial production of microbial enzymes has been shown in Fig. 1.

Enzymes, particularly of microbial origin, can be cultured largely by gene manipulations, as per the need for industrial applications. Applications of microbial enzymes in food, pharmaceutical, textile, paper, leather, and other industries are numerous and increasing rapidly over conventional methods due to less harm to the environment, greater efficiency, and the higher quality products (Jordon 1929; Kamini et al. 1999; Gurung et al. 2013).

Table 1 Enzyme classes, types of reactions and corresponding enzymes

\begin{tabular}{|c|c|c|c|}
\hline S. no. & Class & Reactions & Enzymes \\
\hline 1 & Oxidoreductases & $\begin{array}{l}\text { Transfer of hydrogen or oxygen or electrons } \\
\text { between molecules }\end{array}$ & $\begin{array}{l}\text { Dehydrogenases, oxidases, oxygenases, } \\
\text { peroxidases }\end{array}$ \\
\hline 2 & Transferases & $\begin{array}{l}\text { Transfer of groups of atoms from one molecule } \\
\text { to another }\end{array}$ & $\begin{array}{l}\text { Fructosyltransferases, transketolases, } \\
\text { acyltransferases, transaminases }\end{array}$ \\
\hline 3 & Hydrolases & Hydrolytic cleavage of bonds & $\begin{array}{l}\text { Proteases, amylases, acylases, lipases, } \\
\text { phosphatases, cutinases }\end{array}$ \\
\hline 4 & Lyases & $\begin{array}{l}\text { Non-hydrolytic cleavage by elimination or } \\
\text { addition reactions }\end{array}$ & $\begin{array}{l}\text { Pectate lyases, hydratases, dehydratases, } \\
\text { decarboxylases, fumarase, argino } \\
\text { succinase }\end{array}$ \\
\hline 5 & Isomerases & $\begin{array}{l}\text { Transfer of group from one position to another } \\
\text { within one molecule }\end{array}$ & Isomerases, epimerases, racemases \\
\hline 6 & Ligases & $\begin{array}{l}\text { Covalent joining of two molecules coupled with } \\
\text { the hydrolysis of an energy rich bond in ATP } \\
\text { or similar triphosphates }\end{array}$ & Synthetases, ligases \\
\hline
\end{tabular}


Table 2 Industrial applications of microbial enzymes

\begin{tabular}{|c|c|c|c|}
\hline Industry & Enzyme & Function & Microorganisms \\
\hline \multirow[t]{7}{*}{ Dairy } & Acid proteinase & Milk coagulation & Aspergillus sp. \\
\hline & Neutral proteinase & Faster cheese ripening, debittering & Bacillus subtilis, A. oryzae \\
\hline & Lipase & Faster cheese ripening, flavor customized cheese, & Aspergillus niger, A. oryzae \\
\hline & $\begin{array}{l}\text { Lactase }(\beta- \\
\quad \text { galactosidase })\end{array}$ & Lactose reduced milk and whey products & Escherichia coli, Kluyveromyces sp. \\
\hline & Aminopeptidase & Faster cheese ripening & Lactobacillus sp. \\
\hline & catalase & Cheese processing & Aspergillus niger \\
\hline & Transglutaminase & Protein cross linking & Streptomyces sp. \\
\hline \multirow[t]{7}{*}{ Baking } & Amylase & Flour adjustment, bread softness & Aspergillus sp., Bacillus sp. \\
\hline & Maltogenic & Enhance shelf life of breads & Bacillus stearothermophilus \\
\hline & $\alpha$-Amylase & & \\
\hline & Xylanase & Dough conditioning & Aspergillus niger \\
\hline & Lipase & Dough stability and conditioning & Aspergillus niger \\
\hline & Glucose oxidase & Dough strengthening & Aspergillus niger, Penicillium chrysogenum \\
\hline & Transglutaminase & Laminated dough strength & Streptoverticillium sp., streptomyces sp. \\
\hline \multirow[t]{11}{*}{ Beverage } & Pectinase & Depectinization & Aspergillus oryzae, Penicillium funiculosum \\
\hline & Glucose oxidase & Oxygen removal from beer & Aspergillus niger \\
\hline & Cellulase & Fruit liquefaction & Aspergillus niger, Trichoderma atroviride \\
\hline & $\alpha$-Amylase & Starch hydrolysis & Bacillus, Aspergillus \\
\hline & $\beta$-Amylase & Starch hydrolysis & Bacillus, Streptomyces, Rhizopus \\
\hline & $\beta$-Glucanase & Restrict haze formation & Bacillus subtilis, Aspergillus spp. \\
\hline & protease & Restrict haze formation & Aspergillus niger \\
\hline & Pullulanase & Starch saccharification & Bacillus sp., Klebsiella sp. \\
\hline & Naringinase & Debittering & Aspergillus niger \\
\hline & limoninase & Debittering & Aspergillus niger, A. oryzae \\
\hline & Aminopeptidases & Protein breakdown during mashing & Lactobacillus brevis, L. plantarum \\
\hline \multirow[t]{3}{*}{ Animal feed } & Phytase & Hydrolyze phytic acid to release phosphorous & Aspergillus niger \\
\hline & Xylanase & Enhanced digestibility of starch & Aspergillus sp., Bacillus sp. \\
\hline & $\beta$-glucanase & Digestive aid & Aspergillus niger \\
\hline \multirow[t]{6}{*}{ Pulp and paper } & Lipase & Pitch control & Candida Antarctica \\
\hline & Protease & Biofilm removal & Bacillus subtilis \\
\hline & Amylase & Deinking, drainage improvement & Bacillus licheniformis \\
\hline & Xylanase & Bleach boosting & $\begin{array}{l}\text { Trichoderma reesei, Thermomyces lanuginosus, } \\
\text { Aureobasidium pullulans }\end{array}$ \\
\hline & Laccase & Non-chlorine bleaching, delignification & Bacillus subtilis \\
\hline & Cellulase & Deinking, drainage improvement & Bacillus sp., Aspergillus niger \\
\hline \multirow[t]{5}{*}{ Polymer } & Lipase & $\begin{array}{l}\text { Polycondensation, ring-opening polymerization of } \\
\text { lactones, carbonates }\end{array}$ & Candida Antarctica \\
\hline & Laccase & Polymerization of bisphenol A & Trametes hirsuta \\
\hline & Glucose oxidase & Polymerization of anilines & Aspergillus niger, Penicillium chrysogenum \\
\hline & Transglutaminase & Crosslinking of protein & Streptomyces mobaraensis \\
\hline & Tyrosinase & Polymerization of lignin and chitosan & Trichoderma reesei \\
\hline \multirow[t]{6}{*}{ Detergent } & Amylase & Carbohydrate stain removal & Aspergillus sp., Bacillus subtilis \\
\hline & Lipase & Fat stain elimination & Aspergillus oryzae, A. flavus, \\
\hline & Protease & Protein stain removal & Aspergillus oryzae, Bacillus subtilis \\
\hline & Cellulase & Color clarification & Aspergillus niger, Bacillus sp. \\
\hline & Cutinase & Triglyceride removal & Fusarium solani f. pisi \\
\hline & Mannanase & Mannan spot removal & Bacillus sp. \\
\hline
\end{tabular}


Table 2 continued

\begin{tabular}{|c|c|c|c|}
\hline Industry & Enzyme & Function & Microorganisms \\
\hline \multirow[t]{4}{*}{ Leather } & Alkaline protease & Dehairing, bating & Alcaligenes faecalis \\
\hline & Neutral Protease & Dehairing, soaking & Aspergillus niger, A. flavus, Bacillus subtilis \\
\hline & Lipase & Degreasing & Aspergillus oryzae, A. flavus, \\
\hline & Amylase & Fiber splitting & Aspergillus sp., Bacillus subtilis \\
\hline \multirow[t]{5}{*}{ Cosmetics } & $\begin{array}{l}\text { Superoxide } \\
\text { dismutase }\end{array}$ & Free radical scavenging, skin care & $\begin{array}{l}\text { Corynebacterium } \\
\text { Glutamicum Lactobacillus plantarum }\end{array}$ \\
\hline & Protease & Removal of dead skin & Aspergillus niger, A. flavus, Bacillus subtilis \\
\hline & Endoglycosidase & Teeth and gum tissue care & Mucor hiemalis \\
\hline & laccase & Hair dye & Bacillus subtilis, Trametes versicolor \\
\hline & lipase & Skin care & Aspergillus oryzae, A. flavus \\
\hline \multirow[t]{6}{*}{$\begin{array}{l}\text { Organic } \\
\text { synthesis }\end{array}$} & Lipase & $\begin{array}{l}\text { Synthesis of pharmaceuticals, polymers, biodiesels, } \\
\text { biosurfactants }\end{array}$ & Aspergillus oryzae, A. flavus \\
\hline & $\begin{array}{l}\text { Glycosyl } \\
\text { tranferase }\end{array}$ & Synthesis of oligosaccharides & Bacillus sp. \\
\hline & Nitrile hydratase & Synthesis of acrylamide, butyramide, nicotinamide & $\begin{array}{l}\text { Rhodococcus rhodochrous PA-34, Bacillus sp. } \\
\text { APB-6 }\end{array}$ \\
\hline & $\begin{array}{l}\text { Glucose } \\
\text { isomerase }\end{array}$ & Production of High fructose corn syrup & Corynebacterium sp., streptomyces murinus \\
\hline & Acyltransferase & Synthesis of hydroxamic acids & Bacillus sp. APB-6 \\
\hline & Laccase & $\begin{array}{l}\text { Production of textile dyes, cosmetic pigments, flavor } \\
\text { agents, and pesticides }\end{array}$ & Trametes versicolor, Bacillus subtilis \\
\hline \multirow{11}{*}{$\begin{array}{l}\text { Waste } \\
\text { management }\end{array}$} & Amidase & Degradation of nitriles containing wastes & Rhodococcus erythropolis \\
\hline & Amylase & Bioremediation of vegetables wastes & B. licheniformis, Aspergillus sp. \\
\hline & Amyloglucosidase & Starch hydrolysis for bioremediation & Aspergillus niger \\
\hline & Lipase & Degradation of crude oil hydrocarbons & Aspergillus oryzae, Candida tropicalis \\
\hline & Nitrile hydratase & Degradation of nitriles containing wastes & Rhodococcus sp. \\
\hline & Protease & Bioremediation of keratinic wastes & Chrysosporium keratinophilum \\
\hline & Laccase & $\begin{array}{l}\text { Degradation of waste containing olefin unit, } \\
\text { polyurethane and phenolic compounds }\end{array}$ & Trametes versicolor \\
\hline & Cutinase & Degradation of plastics, Polycaprolactone & Fusarium solani $f$. pisi \\
\hline & $\begin{array}{l}\text { Manganese } \\
\text { peroxidase }\end{array}$ & Degradation of phenolic compounds & $\begin{array}{l}\text { Phanerochaete chrysosporium, Coprinus } \\
\text { cinereus }\end{array}$ \\
\hline & Lignin peroxidase & Degradation of phenolic compounds & $\begin{array}{l}\text { Phanerochaete chrysosporium, Coprinus } \\
\text { cinereus }\end{array}$ \\
\hline & Oxygenase & Degradation of halogenated contaminants & Pseudomonas sp., Rhodococcus sp. \\
\hline
\end{tabular}

In this review, the attentions are given to present a succinct role of all microbial enzymes involved in various fields of technical applications, such as feed industry, food processing and cosmetics. Furthermore, efforts are made to draw a simple and clear scenario about the industrial structure of global enzyme market.

\section{The use of enzymes in industrial processes}

Enzymes are used in industrial processes, such as baking, brewing, detergents, fermented products, pharmaceuticals, textiles, leather processing. Here are a range of processes showing how enzymes are used.

\section{Pharmaceutical and analytical industry}

Enzymes have many significant and vital roles in the pharmaceutical and diagnostic industries. These are extensively used as therapeutic drugs in health issues associated with enzymatic deficiency and digestive disorders, and in diagnostic procedures such as ELISA and diabetes testing kits (Mane and Tale 2015).

Enzyme applications in medicine are as extensive as in industry and are growing rapidly. At present, most prominent medical uses of microbial enzymes are removal of dead skin, and burns by proteolytic enzymes, and clot busting by fibrinolytic enzymes. Nattokinase (EC 3.4.21.62), a potent fibrinolytic enzyme, is a promising 


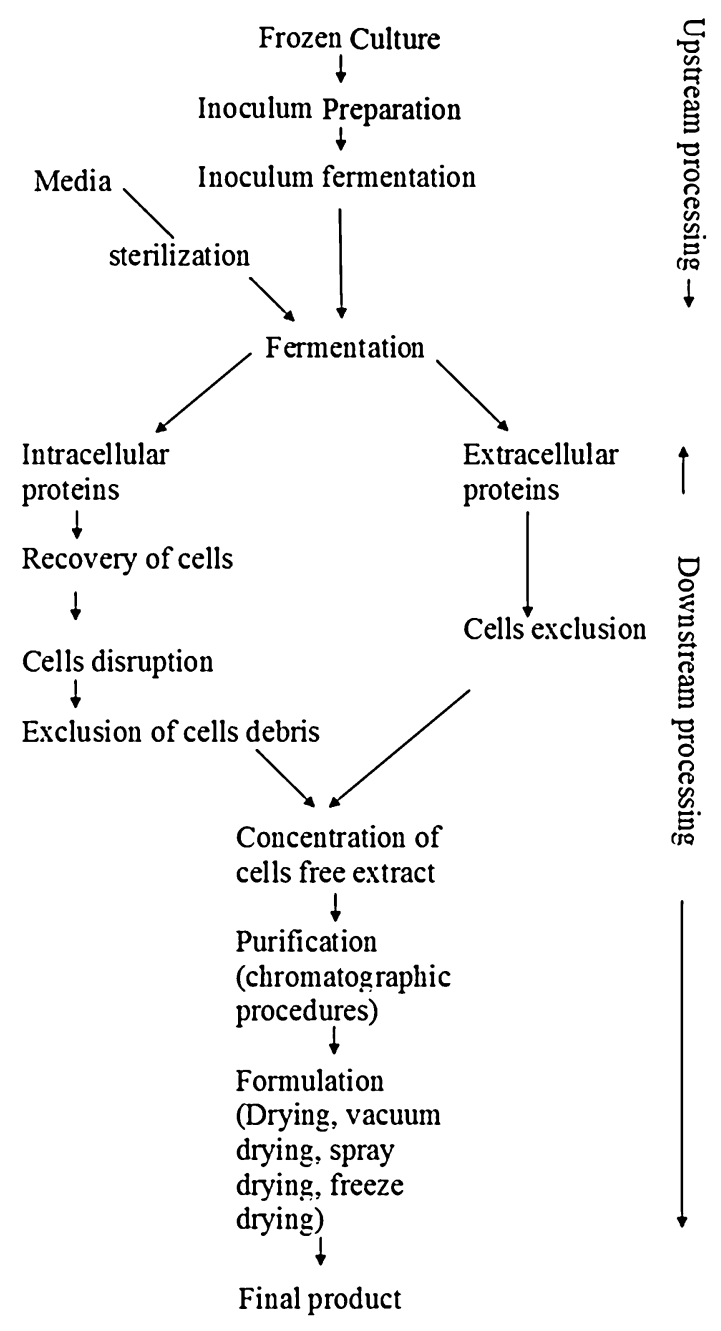

Fig. 1 Industrial production of enzymes

agent for thrombosis therapy (Sumi et al. 1987; Cho et al. 2010). Acid protease, dextranase (EC 2.4.1.2) and rhodanase (EC 2.8.1.1) may be used to treat alimentary dyspepsia, tooth decay and cyanide poisoning, respectively (Okafor 2007). Lipases (EC 3.1.1.3) are the most frequently used enzymes in the organic synthesis and are used in the synthesis of optically active alcohols, acids, esters, and lactones (Cambou and Klibanov 1984; Saxena et al. 1999). Microbial lipases and polyphenol oxidases (EC 1.10.3.2) are involved in the synthesis of (2R,3S)-3-(4methoxyphenyl) methyl glycidate (an intermediate for diltiazem) and 3, 4-dihydroxylphenyl alanine (DOPA, for treatment of Parkinson's disease), respectively (Faber 1997). Tyrosinase (EC 1.14.18.1), an important oxidase enzyme, is involved in melanogenesis and in the production of L-Dihydroxy phenylalanine (L-DOPA). L-DOPA is used as a precursor for the production of dopamine which is a potent drug for the treatment of Parkinson's disease and to control the myocardium neurogenic injury (Ikram-
ul-Haq et al. 2002; Zaidi et al. 2014). Chitosanase (EC 3.2.1.132) catalyze hydrolysis of chitosan to biologically active chitosan oligosaccharides (COS), which is used as antimicrobial, antioxidant, lowering of blood cholesterol and high blood pressure, controlling arthritis, protective effects against infections and improving antitumor properties (Kim and Rajapakse 2005; Ming et al. 2006; Zhang et al. 2012; Thadathil and Velappan 2014). Applications of microbial enzymes for different health problems are illustrated in Table 3 (Devlin 1986; Kaur and Sekhon 2012; Sabu 2003; Vellard 2003; Mane and Tale 2015).

The extensive utilization of enzymes for scientific and analytical purposes is used to estimate the concentration of substrates and to determine the catalytic activity of enzymes present in biological samples. Advances in the enzyme technology have replaced or minimized the use to harmful radioactive elements in different immunoassays, which are used for the determination of a variety of proteins and hormones (Palmer 2001).

Furthermore, enzymes are used in clinical diagnostic for the quantitative determination of diabetes and other health disorders, for example, glucose oxidase (EC 1.1.3.4) for glucose; urease (EC 3.5.1.5) and glutamate dehydrogenase (EC 1.4.1.2) for urea; lipase, carboxyl esterase, and glycerol kinase for triglycerides; urate oxidase (EC 1.7.3.3) for uric acid; creatinase (EC 3.5.3.3) and sarcosine oxidases (EC 1.5.3.1) for creatinine (Dordick 2013; Le Roes-Hill and Prins 2016). Cholesterol oxidase (EC 1.1.3.6) has also been reported for useful biotechnological applications in the detection and conversion of cholesterol. Putrescine oxidase (EC 1.4.3.10) is used to detect biogenic amines, such as putrescine, a marker for food spoilage (Le RoesHill and Prins 2016).

Enzymes are indispensable in nucleic acid manipulation for research and development in the field of genetic engineering, such as restriction endonucleases are used for site specific cleavage of DNA for molecular cloning (Newman et al. 1995) and DNA polymerases for the DNA amplification by polymerase chain reaction (PCR).

\section{Food industry}

United Nation Department of Economic and Social Affairs (UNDESA) estimates that world population is predicted to grow from 6.9 billion to 9.1 billion and food demand is expected to increase by $70 \%$ by 2050 (http://www.un.org/ waterforlifedecade/food_security.shtml). Quality food supply issue can be addressed by the application of enzymes in the food industry. These biomolecules are efficiently involved in improving food production and components, such as flavor, aroma, color, texture, appearance and nutritive value (Neidleman 1984). The profound understanding of the role of enzymes in the food 
Table 3 Some therapeutic applications of microbial enzymes

\begin{tabular}{|c|c|c|}
\hline Treatment & Enzymes & Microorganisms \\
\hline Antitumor & $\begin{array}{l}\text { L-Asparaginase, L-glutaminase, L-tyrosinase, } \\
\text { galactosidase }\end{array}$ & $\begin{array}{l}\text { Escherichia coli, Pseudomonas acidovorans, } \\
\text { Beauveria bassiana, Acinetobacter }\end{array}$ \\
\hline Antiinflammatory & Superoxide dismutase, Serrapeptase & $\begin{array}{l}\text { Lactobacillus plantarum, Nocardia sp., } \\
\text { Mycobacterium sp., Corynebacterium } \\
\text { Glutamicum, }\end{array}$ \\
\hline Anticoagulants & Streptokinase, urokinase & Streptococci sp., Bacillus subtilis \\
\hline Antibiotic synthesis & Penicillin oxidase, rifamycin B oxidase & Penicillium sp. \\
\hline Antioxidants & $\begin{array}{l}\text { Superoxide dismutases, glutathione peroxidases, } \\
\text { catalase }\end{array}$ & $\begin{array}{l}\text { Lactobacillus plantarum, Corynebacterium } \\
\text { glutamicum }\end{array}$ \\
\hline Skin ulcers & Collagenase & Clostridium perfringens \\
\hline Detoxification & Laccase, rhodanese & Pseudomonas aeruginosa \\
\hline Antibiotic resistance & $\beta$-Lactamase & $\begin{array}{l}\text { Klebsiella pneumonia, Citrobacter freundii, } \\
\text { Serratia marcescens }\end{array}$ \\
\hline Antiviral & Ribonuclease, Serrapeptase & Saccharomyces cerevisiae \\
\hline Gout & Uricase & Aspergillus flavus \\
\hline Digestive disorders & $\alpha$-Amylase, lipase & Bacillus spp., Candida lipolytica, A. oryzae \\
\hline Cyanide poisoning & Rhodanase & Sulfobacillus sibiricus \\
\hline
\end{tabular}

manufacturing and ingredients industry have improved the basic processes to provide better markets with safer and higher quality products. Furthermore, the enzymes gained interest in new areas such as fat modification and sweetener technology ( $\mathrm{Li}$ et al. 2012). Currently, the food and beverage segment dominated the industrial enzyme market and it is projected to reach a value of $\$ 2.3$ billion by 2020 (2015c: Industrial Enzymes Market). In beverage and food industry, enzymes are added to control the brewing process and produce consistent, high-quality beer; to enhance the functional and nutritional properties of animal and vegetables proteins by the enzymatic hydrolysis of proteins, for higher juice yield with improved color and aroma.

The application of enzymes in food industry is segmented into different sectors, such as baking, dairy, juice production and brewing. Worldwide, microbial enzymes are efficiently utilized in bakery - the principal application market in food industry - to improve dough stability, crumb softness and structure, and shelf life of products. Increased uses of microbial enzymes in cheese processing are largely responsible for the use of enzymes in dairy industry, which is the next largest application industry followed by the beverages industry.

\section{Baking industry}

Baking enzymes are used for providing flour enhancement, dough stability, improving texture, volume and color, prolonging crumb softness, uniform crumb structure and prolonging freshness of bread. To meet rising demand for quality, enzymes are seen as natural solutions in today's baking market. The baking enzymes industry is expected to reach $\$ 695.1$ million by 2019 growing at a CAGR $8.2 \%$ from 2013 to 2019 (2014a: Baking Enzymes Market).

Bread making is one of the most common food processing techniques globally. The use of enzymes in bread manufacturing shows their value in quality control and efficiency of production. Amylase, alone or in combination with other enzymes, is added to the bread flour for retaining the moisture more efficiently to increase softness, freshness and shelf life. Additionally, lipase and xylanase (EC 3.2.1.8) are used for dough stability and conditioning while glucose oxidase and lipoxygenase added to improve dough strengthening and whiteness. Transglutaminase (EC 2.3.2.13) is used in baking industry to enhance the quality of flour, the amount and texture of bread and the texture of cooked pasta (Kuraishi et al. 1997; Moore et al. 2006; Kieliszek and Misiewicz 2014). Lipases are also used to improve the flavor content of bakery products by liberating short-chain fatty acids through esterification and to prolong the shelf life of the bakery products (Andreu et al. 1999; Dauter et al. 1999; Monfort et al. 1999; Collar et al. 2000; Kirk et al. 2002; Fernandes 2010; Li et al. 2012; Adrio and Demain 2014).

\section{Dairy industry}

Dairy enzymes, an important segment of food enzyme industry, are used for the development and enhancing organoleptic characteristics (aroma, flavor and color) and higher yield of milk products. The use of enzymes (proteases, lipases, esterases, lactase, aminopeptidase, lysozyme, lactoperoxidase, transglutaminase, catalase, etc.) in 
dairy market is well recognized and varies from coagulant to bio-protective enzyme to enhance the shelf life and safety of dairy products. Dairy enzymes are used for the production of cheese, yogurt and other milk products (Pai 2003; Qureshi et al. 2015).

Rennet, a combination of chymosin and pepsin, is used for coagulation of milk into solid curds for cheese production and liquid whey. Currently, approximately $33 \%$ of global demand of cheese produced using microbial rennet. Other proteases find applications for accelerated cheese processing and in reduction of allergenic properties of milk products (Qureshi et al. 2015). Currently, lipases are involved in flavor improvement, faster cheese preparation, production of customized milk products, and lipolysis of milk fat (Sharma et al. 2001; Ghosh et al. 1996). Transglutaminase catalyzes polymerization of milk proteins and improves the functional properties of dairy products (Rossa et al. 2011; Kieliszek and Misiewicz 2014).

Lactose intolerance is the lack of ability of human being to digest lactose due to deficiency of lactase enzyme. Lactase ( $\beta$-galactosidase, EC 3.2.1.23) catalyzes hydrolysis of lactose to glucose and galactose, and therefore, is used as a digestive aid and to enhance the solubility and sweetness in milk products (Soares et al. 2012; Qureshi et al. 2015). It is required to minimize or removal of lactose content of milk products for lactose-intolerant people to prevent severe tissue dehydration, diarrhea, and sometimes fatal consequences (Kardel et al. 1995; Pivarnik et al. 1995; Mahoney 1997).

\section{Beverages industry}

The beverage industry is divided into two major groups and eight sub-groups. The nonalcoholic group contains soft drink and syrup, packaged water, fruit juices along with tea and coffee industry. Alcoholic group comprised distilled spirits, wine and beer (Encyclopedia of Occupational health and safety). Industrial enzymes are used in breweries as processing aids and to produce consistent and highquality products. In the brewing industries, microbial enzymes are used to digest cell wall during extraction of plant material to provide improved yield, color, and aroma and clearer products (Kårlund et al. 2014).

The enzyme applications are an integrating ingredient of the current fruit and vegetable juice industry. Enzymes are used in fruit and vegetable juice industry as processing aids to increase the efficiency of operation, for instance, peeling, juicing, clarification, extraction and improve the product quality (Law 2002). Application of cellulases, amylases, and pectinases during fruit juice processing for maceration, liquefaction, and clarification, improve yield and cost effectiveness (Kumar 2015; Garg et al. 2016). The quality and stability of juices manufactured are enhanced by the addition of enzymes. Enzymes digest pectin, starch, proteins and cellulose of fruits and vegetables and facilitate improved yields, shortening of processing time and enhancing sensory characteristics (Mojsov 2012). Amylases are used for clarification of juices to maximize the production of clear or cloudy juice (Vaillant et al. 2001; Sivaramakrishnan et al. 2006). Cellulases and pectinases are used to improve extraction, yield, cloud stability and texture in juices (Bhat 2000; Kashyap et al. 2001; Garg et al. 2016). Naringinase (EC 3.2.1.40) and limoninase, debittering enzymes, hydrolyze bitter components and improves the quality attributes of citrus juices (Hotchkis and Soares 2000; Li et al. 2012). Pectin, a structural heteropolysaccharide, present in nearly all fruits is required to be maintained to regulate cloudiness of juices by polygalacturonase (EC 3.2.1.15), pectin esterases (EC 3.1.1.11), pectin lyase (EC 4.2.2.10) and various arabanases (Kashyap et al. 2001; Yadav et al. 2001).

Microbial amylases may be utilized in the distilled alcoholic beverages to hydrolyze starch to sugars prior to fermentation and to minimize or remove turbidities due to starch. The application of enzymes to hydrolyze unmalted barley and other starchy adjuncts facilitate in cost reduction of beer brewing. In brewing, development of chill-hazes in beer may be control by the addition of proteases (Okafor 2007).

\section{Feed industry}

To meet the continuously increasing worldwide demand of milk and meat consumption, growth of feed enzymes occurred steadily. The use of enzymes in animal diets initiated in the 1980s and exploded in the 1990s. Feed enzymes are gaining importance as they can increase the digestibility of nutrients and higher feed utilization by animals (Choct 2006). The global market for feed enzymes was estimated $\$ 899.19$ million in 2014 and expected to reach nearly $\$ 1.3$ billion by 2020 , at a CAGR of $7.3 \%$ from 2015 to 2020 (2015a: Feed Enzyme Market).

Feed enzymes may be used in animal diet formulation. For instance, these are added to degrade specific feed components which are otherwise harmful or no nutritional value. In addition, the protein dietary value of feeds available for poultry may also be enhanced by the application of feed enzymes (Collection of information on enzymes 2002). Feed enzymes mainly used for poultry are phytases, proteases, $\alpha$-galactosidases, glucanases, xylanases, $\alpha$-amylases, and polygalacturonases (Walsh et al. 1993; Chesson 1993; Bhat 2000; Adrio and Demain 2014). The phytase, largest enzyme segment in the feed industry, is used to utilize natural phosphorous bound in phytic acid in cereal-based feed (Lei and Stahl 2000; Bhat 2000; Frias et al. 2003). Monogastric animals are unable to digest plant based feeds containing high amount of cellulose and 
hemicelluloses. Xylanase and $\beta$-glucanase are added to their feeds as these enzymes fully degrade and digest high amount of starch (Bhat 2000; Kirk et al. 2002). Proteases are also used in animal feeds to overcome anti-nutritional factors by degrading proteins into their constituent amino acids. Apart from improving the nutritional value of feed for better feed conversion by the animals, these feed enzymes are gaining importance for their role in feed cost reduction and meat quality improvement (Lei and Stahl 2001; Adrio and Demain 2014).

\section{Polymer industry}

To meet the increased consumption of polymers and the growing concern for human health and environmental safety has led to the utilization of microbial enzymes for synthesis of biodegradable polymer. In vitro enzyme catalyzed synthesis of polymer is an environmental safe process having several advantages over conventional chemical methods (Vroman and Tighzert 2009; Kadokawa and Kobayashi 2010). Biopolymers are environmentally friendly materials as these are synthesized from renewable carbon sources via biological processes, degrade biologically after use and return to the natural environment as renewable resources, such as $\mathrm{CO}_{2}$ and biomass (Hiraishi and Taguchi 2009). Biopolymers, such as polyesters, polycarbonates and polyphosphates are used in various biomedical applications, e.g., orthopedic devices, tissue engineering, adhesion barriers, control drug delivery, etc. (Gunatillake and Adhikari 2003; Ulery et al. 2011).

The biopolymers market is growing at a CAGR of $14.5 \%$ due to high penetration of materials in industries like medical, packaging, appliances, automotive, electronics, and furniture and the market is expected to reach nearly $\$ 3.6$ billion by 2018 (2014b: Bioplastics \& Biopolymers Market). Increasing demand of packaging materials and environmental safety can be addressed by the biodegradable polymers. Lipases catalyze the polymerization of lactones, cyclic diesters and cyclic carbonates to produce polyesters or polycarbonates (Kobayashi 2010). Lipase catalyzed polymerization is an eco-friendly technique for the preparation of useful polyesters by polycondensation as well as poly-addition reactions (Vroman and Tighzert 2009). The other enzymes involved in biopolymer industries are laccase (EC 1.10.3.2), peroxidase and transglutaminase for forming cross-links in biopolymers to produce materials in situ by means of polymerization processes (Gurung et al. 2013).

\section{Paper and Pulp industry}

With increasing awareness of sustainability issues, uses of microbial enzymes in paper and pulp industry have grown steadily to reduce adverse effect on ecosystem. The utilization of enzymes reduce processing time, energy consumption and amount of chemicals in processing. Enzymes are also used to enhance deinking, and bleach in paper and pulp industry and waste treatment by increasing biological oxygen demand (BOD) and chemical oxygen demand (COD) (Srivastava and Singh 2015). Xylanases and ligninases are used in paper and pulp industries to augment the value of the pulp by removing lignin and hemicelluloses (Maijala et al. 2008). In these industries, amylases uses include starch coating, deinking, improving paper cleanliness and drainage improvement (Kuhad et al. 2011). Lipases are employed for deinking and enhancing pitch control while cellulases are used for deinking, improving softness and drainage improvement (Kirk and Jeffries1996). Cellulase has also been used for the development of the bioprocess for recycling of used printed papers (Patrick 2004). The application of laccase is an alternative to usage and requirement of large amount of chlorine in chemical pulping process; subsequently, reduce the waste quantity that causes ozone depletion and acidification (Fu et al. 2005). Moreover, mannases are used for degrading glucomannan to improve brightness in paper industry (Clarke et al. 2000).

\section{Leather industry}

The leather industry is more customary, and therefore, discharges and waste disposed from different stages of leather processing are causing severe health hazards and environmental problems (Choudhary et al. 2004). The biodegradable enzymes are efficient alternative to improve the quality of leather and help to shrink waste (Adrio and Demain 2014). The initial attempt for application of enzyme in leather industry was made for dehairing process, the largest process in leather preparation which require bulk amount of enzymes like proteases, lipases and amylases (Sankaran 1995; Bailey 1992; Raju et al. 1996). Enzymatic dehairing applications are attractive because it can preserve the hair and contribute to fall in the organic load released into the effluent. Enzymatic dehairing processes minimize or eliminate the dependence on harmful chemicals, such as sulfide, lime and amines (Green 1952; Money 1996; de-Souza and Gutterres 2012).

Enzymes are required for facilitating procedure and enhancing leather quality during different stages in leather processing, such as, curing, soaking, liming, dehairing, bating, picking, degreasing and tanning (Mojsov 2011). The enzymes used in leather industries are alkaline proteases, neutral proteases, and lipases. Alkaline proteases are used to remove non fibrillar proteins during soaking, in bating to make leather soft, supple and pliable. Neutral and alkaline proteases, both are used in dehairing to reduce water wastage (Rao et al. 1998). In addition to this, lipases 
are used during degreasing to remove fats (Choudhary et al. 2004; Sharma et al. 2001). The advantages of using enzymes instead of chemicals in liming are stainless pelt, reduced odor, low $\mathrm{BOD}$ and $\mathrm{COD}$ in effluents, and improved hair recovery (Bhatia 2003).

\section{Textile industry}

The textile industry is responsible for vast generation of waste from desizing of fabrics, bleaching chemicals and dye is one of the largest contributors to environmental pollution (Ahuja et al. 2004). In such industries, enzymes are used to allow the development of environmentally friendly technologies in fiber processing and strategies to improve the final product quality (Choi et al. 2015). The main classes of enzymes involved in cotton pre-treatment and finishing processes are hydrolase and oxidoreductase. The group of hydrolase includes amylase, cellulase, cutinase, protease, pectinase and lipase/esterase, which are involved in the biopolishing and bioscouring of fabric, antifelting of wool, cotton softening, denim finishing, desizing, wool finishing, modification of synthetic fibers, etc. (Araujo et al. 2008; Chen et al. 2013). Oxidoreductase, other group of enzyme, includes catalase, laccase, peroxidase, and ligninase, which are involved in bio-bleaching, bleach termination, dye decolorization, fabric, wool finishing, etc. (Mojsov 2011). A brief detail of applications of enzymes in textiles industries are shown in Table 4.

\section{Enzymes in cosmetics}

The applications of enzymes in cosmetics have been continuously increased. Enzymes are used as free radical scavengers in sunscreen cream, toothpaste, mouthwashes, hair waving and dyeing ( $\mathrm{Li}$ et al. 2012). The superoxide dismutase (SOD, EC 1.15.1.1) is used to arrest free radicals and to control damage to skin caused by air and water pollutions, microbes and other harmful factors. SOD and peroxidases are used in combination in sunscreen cream as free radical scavengers to reduce erythema (Babizhayev 2006). Proteases are used in skin creams to clean and smoothen the skin through peeling off dead or damaged skin (Cho et al. 2007).

Other widely used enzymes in toothpaste and mouthwash are endoglycosidase and papain, which are used to whiten teeth, to remove plaque and to remove odor-causing deposits on teeth and gum tissue (Buckingham 1985). Laccase, oxidases, peroxidases, and polyphenol oxidases are used in hair dyeing (Lang and Cotteret 2004), lipase, catalase, papain, bromelain and subtilisin in skin care (Diehl 2008); and protein disulfide isomerase, glutathione sulfhydryl oxidase and transglutaminase in hair waving ( $\mathrm{Li}$ et al. 2012). Additionally, enzymes are also used in contact lens cleaners to remove protein films (Alfa and Jackson 2001).

\section{Enzymes in detergents}

Detergents represent the largest industrial application of enzymes amounting to $25-30 \%$ of the total sales of enzymes and expected to grow faster at a CAGR of about $11.5 \%$ from 2015 to 2020 (2014c: Global Market for Enzymes in Industrial Applications). Enzymes have contributed significantly to the growth and development of industrial detergents, which is a prime application area for enzymes today. Detergents are used in miscellaneous applications as dishwashing, laundering, domestic, industrial and institutional cleaning (Schafer et al. 2002). The enzymes in detergent products are used to remove protein, starch, oil and fats based stains and to increase the

Table 4 Uses of enzymes in textile industry

\begin{tabular}{lll}
\hline Enzyme & Use & Microorganisms \\
\hline Amylase & Desizing & Bacillus sp., B. licheniformis \\
Cellulose & Cotton softening, denim finishing & Aspergillus niger, Penicillium funiculosum \\
Catalase & Bleach termination & Aspergillus sp. \\
Laccase & Non-chlorine Bleaching, fabric dyeing & Bacillus subtilis \\
Pectate lyase & Bioscouring & Bacillus sp., Pseudomonas sp. \\
Amylase & Desizing & Bacillus sp., B. licheniformis \\
Cellulose & Cotton softening, denim finishing & Aspergillus niger, Penicillium funiculosum \\
Protease & Removal of wool fiber scales, degumming of silk & Aspergillus niger, B. subtilis \\
Lipase & Removal of size lubricants, denim finishing, & Candida Antarctica \\
Ligninase & Wool finishing & Trametes versicolor, Phlebia radiata \\
Collagenase & Wool finishing & Clostridium histolyticum \\
Cutinase & Cotton scouring, synthetic fiber modification & Pseudomonas mendocina, Fusarium solani pisi, Thermomonospora fusca
\end{tabular}


effectiveness of detergents (Kirk et al. 2002; Hasan et al. 2010). The enzymes in laundry detergents are weight efficient, cleave off damaged cotton fibers, improve whiteness, color and fabric care. Enzymes mainly used in detergent products are of hydrolase group and currently, most commonly used enzymes are amylase and protease. Sometimes a combination of enzymes, including proteases, amylases, pectinases, cellulases and lipases used to increase efficiency on stain cleaning and fabric care ( $\mathrm{Li}$ et al. 2012).

Amylases and lipases are effective on removing starchy food deposits and stains resulting from fatty products, respectively (Masse et al. 2001). Cutinase (EC 3.1.1.74), a hydrolytic enzyme, is used as a lipolytic enzyme in dishwashing and laundry detergents (Filipsen et al. 1998; Pio and Macedo 2009). Protease digests on organic stains, such as grass, blood, egg and human sweat, whereas cellulases are used to brighten colors, soften fabrics and to eliminate small fibers from the fabric without damaging the major fibers of the fabric (Hasan et al. 2010; Kuhad et al. 2011). Protease and amylase are used particularly in dishwasher detergents to remove protein and carbohydrate containing food particles (Keshwani et al. 2015). The application of enzymes in detergent products is advantageous as these products contain less bleaching agents, phosphates, and consequently have beneficial effects on public and environmental health (Olsen and Falholt 1998; Novozyme 2013).

\section{Organic synthesis industry}

Enzyme based processes for production of fine chemicals are rapidly gaining practical significance owing to more economical high purity products in an eco-environmentally acceptable manner (Nagasawa and Yamada 1995). Enzymes are preferred in industrial chemical synthesis over conventional methods for their high selectivity, i.e., chiral, positional and functional group specific (Schmid et al. 2001). Such high selectivity is extremely advantageous in chemical synthesis as it may offer several benefits such as minimal or no by-product formation, easier separation, and less environmental problems. Besides, high catalytic efficiency and mild operational conditions are advantages of enzyme mediated commercial applications. Catalytic potential of microorganisms have been employed for hundreds of years in the production of alcohol, and cheese for industrial synthetic chemistry (Johannes et al. 2006). Among the enzymes in organic synthesis, lipases are the most frequently used, particularly, in the formation of a wide range of optically active alcohols, acids, esters, and lactones (Jaegera and Reetz 1998; Hasan et al. 2006). Lipases are used for the production of $(\mathrm{S}, \mathrm{R})-2,3-p-$ ethoxyphenylglycyclic acid, an intermediate for diltiazem
(Gentile et al. 1992). Oxidoreductases, such as polyphenol oxidase is involved in the synthesis of 3,4-dihydroxylphenyl alanine (DOPA), a chemical used in the treatment of Parkinson's disease (Faber 1997). Oligosaccharides and polysaccharides, play vital roles in cellular recognition and communication processes, are synthesized industrially using high regio- and stereoselectivity of glycosyltransferases (Ginsburg and Robbins 1984). Lyases are involved in organic synthesis of cyanohydrins from ketones, acrylamide from acrylonitrile, malic acid from fumaric acid (Faber 1997; Zaks 2001). The nitrile hydratase mediated process for the production of acrylamide is carried out by the Nitto Chemical Company of Japan at a scale of more than 40,000 tons per year (Zaks 2001). A multi-million ton of high fructose corn syrup (HFCS), an alternative sweetener to sucrose in the food and beverage industry, is produced every year commercially using glucose isomerase (Gerhartz 1990).

\section{Waste treatment}

The use of enzyme for waste management is extensive and a number of enzymes are involved in the degradation of toxic pollutants. The industrial effluents as well as domestic waste contain many chemical commodities, which are hazardous or toxic to the living being and ecosystem. Microbial enzyme(s), alone or in combinations, are used for the treatment of industrial effluents containing phenols, aromatic amines, nitriles, etc., by degradation or bioconversion of toxic chemical compound(s) to innocuous products (Klibanov et al. 1982; Raj et al. 2006; Rubilar et al. 2008; Pandey et al. 2011). A number of enzymes employed for waste treatment are amidases, amylases, amyloglucosidases, cellulases, glucoamylases, lipases, nitrile hydratases, pectinases and proteases (Margesin et al.1999; Riffaldi et al. 2006; Karigar and Rao 2011). The detoxification of toxic organic compounds through oxidative coupling is mediated with oxidoreductases (Karigar and Rao 2011). These enzymes, like laccase, manganese peroxidase, lignin peroxidase and tyrosinase catalyze the removal of chlorinated phenolic compounds from industrial effluents (Gianfreda et al. 1999; Mai et al. 2000; Have and Teunissen 2001; Piontek et al. 2001; Le Roes-Hill and Prins 2016). The microbial enzymes are also utilized to recycle the waste for reuse, e.g., to recover additional oil from oil seeds, to convert starch to sugar, to convert whey to various useful products (Kalia et al. 2001; http://www. unido.org/fileadmin/import/32068_35FoodWastes). Microbial oxygenases, such as monooxygenases and dioxygenases have a broad substrate range, and are active against a wide range of compounds, including the chlorinated aliphatics (Fetzner and Lingens 1994; Arora et al. 2009). These are used in the degradation of halogenated organic 
compounds containing pollutants, like herbicides, insecticides, fungicides, hydraulic and heat transfer fluids, plasticizers, and intermediates for chemical synthesis (Fetzner and Lingens 1994; Karigar and Rao 2011).

\section{Indian enzymes market}

Around the globe, enzyme market is dominated by the food and beverage products, and drug industry that go directly or indirectly for human consumption. The biggest challenge in front of fast growing economies such as India is to provide food and healthcare to even their larger population. India, an agriculture-based economy, is predicted to grow at $7.9 \%$ by 2018 (http://data.worldbank.org/country/india) and an attractive market that is opening her doors for industrial enzyme based manufacturing sector. Indian biotech sector accounts $2 \%$ of the global biotech market, but it is gaining worldwide visibility due to the investment opportunities as well as its research output (Binod et al. 2013). Recently, Bharat Biotech, a Hyderabad-based pharma company, has developed world first Zika virus vaccine, which is ready for pre-clinical trials (http://www. huffingtonpost.in/2016/02/07/zika-virus_0_n_9179776.

html), demonstrating the "Make in India" efforts (http:// www.makeinindia.com/sector/biotechnology).
Pharmaceutical enzymes cover almost $50 \%$ of total enzyme demand in India, followed by detergent enzymes (20\%) and textile enzymes (20\%) (Binod et al. 2013).

In 2012, industrial enzymes market globally including the market in India was at marginal position with a net value of around $\$ 105$ million, but expected to grow significantly with an average of $\geq 10 \%$ per year through 2017 to reach nearly $\$ 173$ (http://www.sebi.gov.in/cms/sebi data/attachdocs/1453372309087.pdf). Greater than $60 \%$ enzyme market in India was contributed by the multinationals companies, whereas the rest was met by the domestic manufacturers. The domestic consumption of enzymes for 2011-12 stood at about $\$ 110$ million, while the exports raked $\$ 32$ million in revenues during this period (Biospectrum 2012). In 2012-13, Advanced Enzymes technologies Ltd., the largest manufacturer and exporter of enzyme products in India, had nearly $30 \%$ share in the enzymes industry and second in line after $44 \%$ market share of Denmark based Novozymes. Other prominent manufacturers were Rossari Biotech, Maps Enzymes, Lumis Biotech and Zytex (CRISIL Research 2013) (Table 5). The demand of enzymes by their type is illustrated in Fig. 2 (CRISIL Research 2013), (http://www.sebi. gov.in/cms/sebi_data/attachdocs/1453372309087.pdf).

Table 5 Industrial enzyme, manufacturers and market share in India (2012-2013)

\begin{tabular}{|c|c|c|c|c|}
\hline Industrial enzymes & Manufacturer & Established & $\begin{array}{l}\text { Indian market share } \\
(\%)\end{array}$ & Applications \\
\hline $\begin{array}{l}\text { Protease, xylanase, } \alpha \text {-amylases, } \\
\text { glucoamylase, etc. }\end{array}$ & $\begin{array}{l}\text { Novozymes } \\
\text { India }\end{array}$ & $\begin{array}{l}1983 \text { (Indian } \\
\text { manufacturing } \\
\text { unit) }\end{array}$ & 44 & $\begin{array}{l}\text { Household care, textiles, food and } \\
\text { beverages, oil and fats, baking, } \\
\text { beverage alcohol etc. }\end{array}$ \\
\hline $\begin{array}{l}\text { Amylase, protease, phytase, xylanase, } \beta \text { - } \\
\text { mannanase, } \alpha \text {-galactosidase, etc. }\end{array}$ & $\begin{array}{l}\text { Advanced } \\
\text { Enzymes } \\
\text { technologies } \\
\text { Ltd. }\end{array}$ & 1989 & 30 & $\begin{array}{l}\text { Food and beverages, pharma, anima } \\
\text { feed, textiles, detergent, biofuel, } \\
\text { etc. }\end{array}$ \\
\hline $\begin{array}{l}\text { Amylases, Proteases, Cellulases, Xylanase, } \\
\text { Glucoamylase, Pectinase, Catalase, } \\
\text { Lipase and Phytase, etc. }\end{array}$ & $\begin{array}{l}\text { MAPS } \\
\text { Enzymes } \\
\text { Ltd. }\end{array}$ & 1975 & $\begin{array}{l}\text { Rest of the Market } \\
\text { share along with } \\
\text { other manufacturers }\end{array}$ & Textile, leather, feed, etc. \\
\hline $\begin{array}{l}\text { Protease, amylase, cellulase, mannanase, } \\
\text { catalase, laccase, pectinases, etc. }\end{array}$ & Rossari biotech & 1997 & & $\begin{array}{l}\text { Textile, pharma, Food and } \\
\text { Beverages, feed, detergent, } \\
\text { chemical, etc. }\end{array}$ \\
\hline $\begin{array}{l}\text { Alkaline Pectinase, Amylase, cellulase, } \\
\text { Laccase, Catalase, lipase, protease, } \\
\text { xylanase, } \beta \text {-glucanase, etc. }\end{array}$ & Lumisbiotech & & & $\begin{array}{l}\text { Textiles, Food and Beverages, feed, } \\
\text { etc. }\end{array}$ \\
\hline $\begin{array}{l}\text { Protease, pectinase, amylase, xylanase } \\
\text { amyloglucosidase, catalases, etc. }\end{array}$ & $\begin{array}{l}\text { Anthem } \\
\text { Cellutions } \\
\text { (India) Ltd }\end{array}$ & 2007 & & $\begin{array}{l}\text { paper, grain processing, beverages, } \\
\text { textiles, baking, animal feed, } \\
\text { pharmaceuticals, etc. }\end{array}$ \\
\hline $\begin{array}{l}\text { Lipase, penicillin amidase, pectinase, } \\
\text { Papain,lysozyme, etc. }\end{array}$ & $\begin{array}{l}\text { Aumgene } \\
\text { Biosciences }\end{array}$ & 2004 & & $\begin{array}{l}\text { Textile, pharma, Food and } \\
\text { Beverages, feed, detergent, etc. }\end{array}$ \\
\hline $\begin{array}{l}\text { Nattokinase, phytase, lipase amylase, } \\
\text { protease, cellulase, etc. }\end{array}$ & $\begin{array}{l}\text { Zytex India } \\
\text { Pvt. Ltd. }\end{array}$ & $\begin{array}{l}1947 \text { (1st } \\
\text { manufacturing } \\
\text { unit in 1996) }\end{array}$ & & $\begin{array}{l}\text { Textile, food, nutraceuticals, animal } \\
\text { feed, etc. }\end{array}$ \\
\hline
\end{tabular}




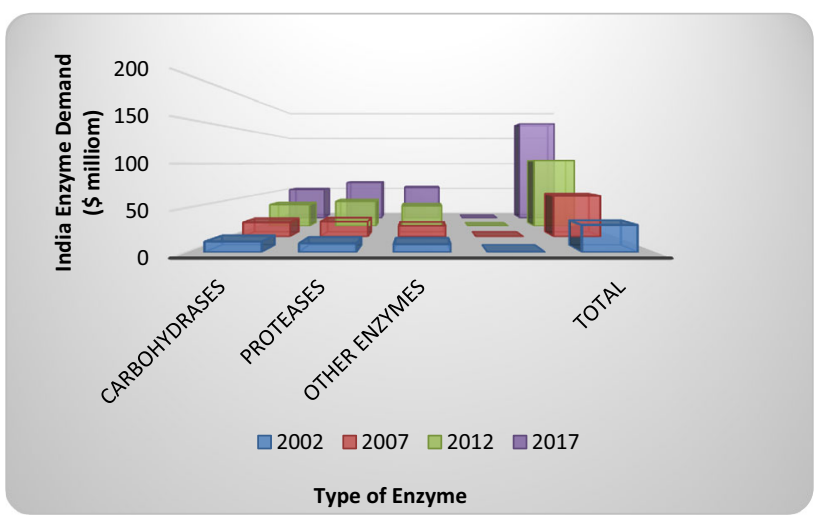

Fig. 2 Industrial enzyme demand in India

\section{Conclusion}

The prospects of industrial uses of microbial enzymes have increased greatly in 21 st century and continuously increasing as enzymes have significant potential for many industries to meet demand of rapidly growing population and cope exhaustion of natural resources. It had been showed here that the enzymes have enormous potential in various industrial sectors that may be pharmaceuticals, food, feed, beverages, detergents, leather processing and paper \& pulp. Alternatively, these biomolecules may be used consistently to meet continuously rising demand of food supply. Enzymes of microbial origin have significant potential in waste management, and consequently in the development of green environment. The enzymes are effectively utilized in many industries for higher quality productions at accelerated rate of reaction with innocuous pollution and cost effectiveness.

\section{Compliance with ethical standard}

Conflict of interest The authors declare that they have no conflict of interest in the publication.

Open Access This article is distributed under the terms of the Creative Commons Attribution 4.0 International License (http:// creativecommons.org/licenses/by/4.0/), which permits unrestricted use, distribution, and reproduction in any medium, provided you give appropriate credit to the original author(s) and the source, provide a link to the Creative Commons license, and indicate if changes were made.

\section{References}

(2014) Baking enzymes market by types (carbohydrase, protease, lipase \& others), by application (bread, biscuits \& cookies, cake \& pastry \& others) \& by geography — global trends \& forecasts to 2019. www.bccresearch.com. http://www.marketsandmarkets. com/market-reports/baking-enzymes-market-250494545.html. Accessed on 23 Mar 2016
(2014) Bioplastics \& biopolymers market by type (Bio PET, Bio PE, PLA, PHA, Bio PBS, starch blends, and regenerated cellulose), by application (packaging, bottles, fibers, agriculture, automotive, and others) \& by geography trends \& forecasts to 2018. http:// www.marketsandmarkets.com. http://www.marketsandmarkets. com/market-reports/biopolymers-bioplastics-market-88795240. html. Accessed on 22 Mar 2016

(2014) Global markets for enzymes in industrial applications 2014. www.bccresearch.com. http://www.bccresearch.com/pressroom/ bio/global-market-industrial-enzymes-reach-nearly-\$7.1-billion2018. Accessed on 26 Feb 2016

(2015) Feed enzymes market by type (phytase, protease, and nonstarch polysaccharides (xylanase, $\beta$-glucanase, cellulase, mannanase \& pectinase), livestock (swine, poultry, ruminants, and aquatic animals) \& by region_-global trends \& forecast to 2020 . www.bccresearch.com. http://www.marketsandmarkets.com/ market-reports/feed-enzyme-market-1157.html. Accessed on 23 Mar 2016

(2015) India industrial enzyme market: forecast and opportunities 2020. http://www.pharmaion.com/report/india-industrial-enzymes-marketforecast-and-opportunities-2020/10.html. Accessed 3 June 2016

(2015) Industrial enzymes market by type (carbohydrases, proteases, non-starch polysaccharides \& others), application (food \& beverage, cleaning agents, animal feed \& others), brands \& by regionglobal trends and forecasts to 2020. www.bccresearch.com. http:// www.marketsandmarkets.com/Market-Reports/industrial-enzymesmarket-237327836.html. Accessed on 24 Mar 2016

Adrio JL, Demain AL (2014) Microbial enzymes: tools for biotechnological processes. Biomolecules 4(1):117-139

Ahuja SK, Ferreira GM, Moreira AR (2004) Utilization of enzymes for environmental applications. Crit Rev Biotechnol 24:125-154

Aldridge S (2013) Industry backs biocatalysis for greener manufacturing. Nat Biotechnol 31:95

Alfa MJ, Jackson M (2001) A new hydrogen peroxide-based medicaldevice detergent with germicidal properties: comparison with enzymatic cleaners. Am J Infect Control 29(3):168-177

Anbu P, Gopinath SC, Chaulagain BP et al (2015) Microbial enzymes and their applications in industries and medicine 2014. Biomed Res Int 2015:1-3

Andreu P, Collar C, Martínez-Anaya MA (1999) Thermal properties of doughs formulated with enzymes and starters. Eur Food Res Technol 209:286-293

Araujo R, Casal M, Cavaco-Paulo A (2008) Application of enzymes for textiles fibers processing. Biocatal Biotechnol 26:332-349

Arora PK, Kumar M, Chauhan A et al (2009) OxDBase: a database of oxygenases involved in biodegradation. BMC Res Notes 2:67

Babizhayev MA (2006) Biological activities of the natural imidazolecontaining peptidomimetics $n$-acetylcarnosine, carcinine and Lcarnosine in ophthalmic and skin care products. Life Sci 78(20):2343-2357

Bailey DG (1992) Handling, greading and curing of hides and skins. In: Pearson AM, Dutson TR (eds) Inedible meat by-products. Springer, pp 19-34. doi: 10.1007/978-94-011-7933-1_2

Bhat MK (2000) Cellulases and related enzymes in biotechnology. Biotechnol Adv 18:355-383

Bhatia SC (2003) Managing industrial pollution. Macmillan India, Delhi

Binod P, Palkhiwala P, Gaikaiwari R et al (2013) Industrial enzymes: present status and future perspectives for India: present scenario and perspectives. J Sci Ind Res 72:271-286

Biospectrum 2012. http://www.biospectrumasia.com/biospectrum/ analysis/2819/indias-industrial-biotech-witnesses-growth

Buckingham KWC (1985) Methods for the treatment and prophylaxis of diaper rash and diaper dermatitis. The Procter \& Gamble Company: Patent No US4556560 A 
Cambou B, Klibanov AM (1984) Preparative production of optically active esters and alcohols using esterase-catalyzed stereospecific transesterification in organic media. J Am Chem Soc 106:2687-2692

Cech TR, Bass BL (1986) Biological catalysis by RNA. Annu Rev Biochem 55:599-629

Chen S, Su L, Chen J, Wu J (2013) Cutinase: characteristics, preparation, and application. Biotechnol Adv 31(8):1754-1767. doi:10.1016/j.biotechadv.2013.09.005

Chesson A (1993) Feed enzymes. Anim Feed Sci Technol 45:65-79

Cho SA, Cho JC, Han SH (2007) Cosmetic composition containing enzyme and amino acid. Amorepacific Corporation (11/ 990):431

Cho YH, Song JY, Kim KM et al (2010) Production of nattokinase by batch and fed-batch culture of Bacillus subtilis. New Biotechnol 27(4):341-346. doi:10.1016/j.nbt.2010.06.003

Choct M (2006) Enzymes for the feed industry: past, present and future. Worlds Poult Sci J 62:5-15

Choi JM, Han SS, Kim HS (2015) Industrial applications of enzyme biocatalysis: current status and future aspect. Biotechnol Adv 33:1443-1454

Choudhary RB, Jana AK, Jha MK (2004) Enzyme technology applications in leather processesing. Ind $\mathbf{J}$ Chem Technol 11:659-671

Clarke JH, Davidson K, Rixon JE et al (2000) A comparison of enzyme aided bleaching of softwood pulp using a combination of xylanase, mannanase and $\alpha$-galactosidase. Appl Microbiol Biotechnol 53:661-667

Collar C, Martinez JC, Andreu P et al (2000) Effect of enzyme associations on bread dough performance: a response surface study. Food Sci Technol Int 6:217-226

Collection of information on enzymes (2002) European Communities. http://ec.europa.eu/environment/archives/dansub/pdfs/ enzymerepcomplete.pdf. Accessed 02 Mar 2016

CRISIL Research 2013. https://www.crisil.com/Ratings/Brochureware/ News/CRISIL\%20Research_ipo_grading_rationale_advanced_ enzymes_technologies.pdf

Dauter Z, Dauter M, Brzozowski AM et al (1999) X-ray structure of Novamyl, the five-domain 'maltogenic' $\alpha$-amylase from Bacillus stearothermophilus: maltose and acarbose complexes at $1.7 \AA$ resolution. Biochemistry 38:8385-8392

De-Souza FR, Gutterres M (2012) Application of enzymes in leather processing: a comparison between chemical and coenzymatic processes. Braz J Chem Eng 29(3):471-481

Devlin TM (1986) Textbook of biochemistry: with clinical correlations ed. Wiley, New York

Diehl C (2008) Skin treatment preparation. Crawford Healthcare Limited: Patent No. US7468195

Dordick JS (2013) Biocatalysts for industry. ISBN 9781475745979

Encyclopedia of occupational health and safety (Beverage industry). http://www.ilocis.org/documents/chpt65e.htm. Accessed 25 Feb 2016

Faber K (1997) Biotransformations in organic chemistry: a textbook. Springer, Berlin

Fernandes P (2010) Enzymes in food processing: a condensed overview on strategies for better biocatalysis. Enzym Res. doi: $10.4061 / 2010 / 862537$

Fersht A (1985) Enzyme structure and mechanism. W.H. Freeman, New York

Fetzner S, Lingens F (1994) Bacterial dehalogenases: biochemistry, genetics, and biotechnological applications. Microbiol Rev 58(4):641-685

Filipsen JAC, Appel ACM, Van Der Hidjen HTWM et al (1998) Mechanism of removal of immobilized triacylglycerol by lipolytic enzymes in a sequential laundry wash process. Enz Microb Technol 23:274-280
Frias J, Doblado R, Antezana JR et al (2003) Inositol phosphate degradation by the action of phytase enzyme in legume seeds. Food Chem 81(2):233-239

Fu GZ, Chan AW, Minns DE (2005) Preliminary assessment of the environmental benefits of enzyme bleaching for pulp and paper making. Int J Life Cycle Assess 10:136-142

Garg G, Singh A, Kaur A et al (2016) Microbial pectinases: an ecofriendly tool of nature for industries. 3 Biotech 6(1):47-59

Gentile A, Giordano C, Fuganti C et al (1992) The enzymic preparation of $(2 \mathrm{R}, 3 \mathrm{~S})$-phenyl glycidic acid esters. J Org Chem 57:6635-6637

Gerhartz W (ed) (1990) Enzymes in industry: production and applications. VCH, New York

Ghosh PK, Saxena RK, Gupta R et al (1996) Microbial lipases: production and applications. Sci Prog 79:119-157

Gianfreda L, Xu F, Bollag JM (1999) Laccases: a useful group of oxidoreductive enzymes. Biorem J 3(1):1-25

Ginsburg V, Robbins PW (1984) Biology of carbohydrates. Wiley, New York

Green GH (1952) Unhairing by means of enzymes. J Soc Leather Traders Chem 36:127-134

Gunatillake PA, Adhikari R (2003) Biodegradable synthetic polymers for tissue engineering. Eur Cell Mater 5:1-16

Gurung N, Ray S, Bose S, Rai V (2013) A broader view: Microbial enzymes and their relevance in industries, medicine and beyond. Biomed Res Int: 1-18. doi:10.1155/2013/329121

Hasan S, Shah AA, Hameed A (2006) Industrial applications of microbial lipases. Enzyme Microb Technol 39:235-251

Hasan F, Shah AA, Javed S, Hameed A (2010) Enzymes used in detergents: Lipases. Afr J Biotechnol 9(31):4836-4844. doi:10. 5897/AJBx09.026

Have RT, Teunissen PJM (2001) Oxidative mechanisms involved in lignin degradation by white-rot fungi. Chem Rev 101(11):3397-3413

Hiraishi T, Taguchi S (2009) Enzyme-catalyzed synthesis and degradation of biopolymers. Mini Rev Org Chem 6:44-54

Hotchkis JH, Soares NFF (2000) The use of active packaging to improve citrus juice quality. International Citrus Congress (9th: 2000: Orlando, Florida), 2003. p 1202-1205

Ikram-ul-Haq, Ali S, Qadeer MA (2002) Biosynthesis of 1-DOPA by Aspergillus oryzae. Bioresour Technol 85(1):25-29

Illanes A, Cauerhff A, Wilson L et al (2012) Recent trends in biocatalysis engineering. Bioresour Technol 115:48-57

Jaegera KL, Reetz MT (1998) Microbial lipases form versatile tools for biotechnology. Trends Biotechnol 16(9):396-403

Johannes T, Simurdiak MR, Zhao H (2006) Biocatalysis. In: Lee S (ed) Encyclopedia of chemical processing. Taylor \& Francis, New York, pp 101-110

Jordon DL (1929) Red heat in salted hides. J Int Soc Leather Trade Chem 13:538-569

Kadokawa JI, Kobayashi S (2010) Polymer synthesis by enzymatic catalysis. Curr Opin Chem Biol 14:145-153

Kalia VC, Rashmi Lal S et al (2001) Using enzymes for oil recovery from edible seeds. J Sci Ind Res 60:298-310

Kamini NR, Hemchander C, Geraldine J et al (1999) Microbial enzyme technology as an alternative to conventional chemical in leather industry. Curr Sci 76:101

Kardel G, Furtado MM, Neto JPM (1995) Lactase na indústria de laticínios. Revista do Instituto de Laticínios "Cândido Tostes" 50(294):15-17

Karigar CS, Rao SS (2011) Role of microbial enzymes in the bioremediation of pollutants: a review. Enzym Res. doi:10.4061/ 2011/805187

Kårlund A, Moor U, Sandell M et al (2014) The impact of harvesting, storage and processing factors on health-promoting phytochemicals in berries and fruits. Processes 2(3):596-624 
Kashyap DR, Vohra PK, Chopra S (2001) Applications of pectinases in the commercial sector: a review. Bioresour Technol 77:215-227

Kaur R, Sekhon BS (2012) Enzymes as drugs: an overview. J Pharm Educ Res 3(2):29-41

Keshwani A, Malhotra B, Kharkwal H (2015) Natural polymer based detergents for stain removal. World J Pharm Pharm Sci 4(4):490-508

Kieliszek M, Misiewicz A (2014) Microbial transglutaminase and its application in the food industry. A review. Folia Microbiol 59:241-250

Kim SK, Rajapakse N (2005) Enzymatic production and biological activities of chitosan oligosaccharides (COS): a review. Carbohydr Polym 62(4):357-368

Kirk TK, Jeffries TW (1996) Role of microbial enzymes for Pulp and Paper Processing. ACS symposium series: Am Chem Soc Washington, DC. pp 2-14. doi:10.1021/bk-1996-0655.ch001

Kirk O, Borchert TV, Fuglsang CC (2002) Industrial enzyme applications. Curr Opin Biotechnol 13:345-351

Klibanov AM, Tu TM, Scott KP (1982) Enzymatic removal of hazardous pollutants from industrial aqueous effluents. Enzym Eng 6:319-323

Kobayashi S (2010) Lipase-catalyzed polyester synthesis-A green polymer chemistry. Proc Jpn Acad Ser B Phys Biol Sci 86(4):338-365

Kuhad RC, Gupta R, Singh A (2011) Microbial cellulases and their industrial applications. Enzym Res. doi:10.4061/2011/ 280696

Kumar S (2015) Role of enzymes in fruit juice processing and its quality enhancement. Adv Appl Sci Res 6(6):114-124

Kuraishi C, Sakamoto J, Yamazaki K et al (1997) Production of restructured meat using microbial transglutaminase without salt or cooking. J Food Sci 62:488-490

Lang G, Cotteret J (2004) Composition for the oxidation dyeing of keratinous fibres containing a laccase and dyeing method using this composition. US2004255401 A1

Law BA (2002) The nature of enzymes and their action in foods. In: Whitehurst RJ, Law BA (eds) Enzyme in food technology. Sheffield Academic Press, Sheffileld, pp 1-18

Le Roes-Hill M, Prins A (2016) Biotechnological potential of oxidative enzymes from Actinobacteria. doi:10.5772/61321

Lei XG, Stahl CH (2000) Nutritional benefits of phytase and dietary determinants of its efficacy. J Appl Anim Res 17:97-112

Lei XG, Stahl CH (2001) Biotechnological development of effective phytases for mineral nutrition and environmental protection. Appl Microbiol Biotechnol 257:474-481

Li S, Yang X, Yang S et al (2012) Technology prospecting on enzymes: application, marketing and engineering. Comput Struct Biotechnol J 2:1-11

Liese A, Seelbach K, Wandrey C (2006) Industrial biotransformations, 2nd edn. Wiley-VCH, Weinheim, pp 273-447

Liu L, Yang H, HD Shin (2013) How to achieve high-level expression of microbial enzymes strategies and perspectives. Bioengineered 4(4):212-223

Mahoney RR (1997) Lactose: enzymatic modification. In: Fox PF (ed) Advanced dairy chemistry-lactose, water, salts and vitamins (2nd edn), Chapman \& Hall, London: pp 77-125

Mai C, Schormann W, Milstein O et al (2000) Enhanced stability of laccase in the presence of phenolic compounds. Appl Microbiol Biotechnol 54(4):510-514

Maijala P, Kleen M, Westin C et al (2008) Biomechanical pulping of softwood with enzymes and white-rot fungus Physisporinus rivulosus. Enzym Microb Technol 43:169-177

Mane P, Tale V (2015) Overview of microbial therapeutic enzymes. Int J Curr Microbiol App Sci 4(4):17-26
Margesin R, Zimmerbauer A, Schinner F (1999) Soil lipase activity-A useful indicator of oil biodegradation. Biotechnol Tech 13(12):859-863

Masse L, Kennedy KJ, Chou S (2001) Testing of alkaline and enzymatic pretreatment for fat particles in slaughterhouses wastewater. Bioresour Technol 77:145-155

Mazzone A, Catalani M, Costanzo M et al (1990) Evaluation of Serratia peptidase in acute or chronic inflammation of otorhinolaryngology pathology: a multicentre, double-blind, randomized trial versus placebo. J Int Med Res 18(5):379-388

Ming M, Kuroiwa T, Ichikawa S et al (2006) Production of chitosan oligosaccharides by chitosanase directly immobilized on an agar gelcoated multidisk impeller. Biochem Eng J 28(3):289-294

Mojsov K (2011) Applications of enzymes in the textile industry: a review. In: 2nd international congress: Engineering, Ecology and Materials in the Processing Industry: Jahorina, Bosnia and Herzegovina; Tehnoloski Fakultet Zvornik, p 230-239

Mojsov K (2012) Microbial alpha-amylases and their industrial applications: a review. Int J Manage IT Eng 2(10):583-609. ISSN 2249-0558

Money CA (1996) Unhairing and dewooling-requirement for quality and the environment. J Soc Leather Tech Chem 80:175-186

Monfort A, Blasco A, Sanz P et al (1999) Expression of LIP1 and LIP2 genes from Geotricum species in baker's yeast strains and their application to the bread-making process. J Agric Food Chem 47:803-808

Moore MM, Heinbockel M, Dockery P, Ulmer MH, Arendt EK (2006) Network formation in gluten-free bread with application of transglutaminase. Cereal Chem 83:28-36

Nagasawa T, Yamada H (1995) Microbial production of commodity chemicals. Pure Appl Chern 67(7):1241-1256

Neidleman SL (1984) Applications of biocatalysis to biotechnology. Biotechnol Gen Eng Rev 1:1-38

Newman M, Strzelecka T, Dorner LF et al (1995) Structure of BamHI endonuclease bound to DNA: partial folding and unfolding on DNA binding. Science 269:656-663

Novozyme: Enzyme at work (2013) 4th edn. http://novozymes.com/ en/about-us/brochures/Documents/Enzymes_at_work.pdf

Okafor N (2007) Biocatalysis: Immobilized enzymes and immobilized cells. Modern Ind Microbiol Biotechnol, p 398. ISBN9781-57808-434-0 (HC)

Olsen HS, Falholt P (1998) The role of enzymes in modern detergency. J Surfactants Deterg 1(4):555-567

Pai JS (2003) Application of microorganisms in food biotechnology. Ind J Biotech 2:382-386

Palmer T (2001) Enzymes: biochemistry, biotechnology and clinical chemistry. Horwood Publishing Ltd, Chichester, pp 345-350

Pandey D, Singh R, Chand D (2011) An improved bioprocess for synthesis of acetohydroxamic acids using DTT (dithiothreitol) treated resting cells of Bacillus sp. APB-6. Bioresour Technol 102(11):6579-6586

Patrick K (2004) Enzyme technology improves efficiency, cost, safety of stickies removal program. Paper Age 120:22-25

Piccolino M (2000) Biological machines: from mills to molecules. Nat Rev Mol Cell Bio 1:149-153

Pio TF, Macedo GA (2009) Chapter 4 Cutinases: properties and industrial applications. Adv Appl Microbiol 66:77-95. doi:10. 1016/S0065-2164(08)00804-6

Piontek K, Smith AT, Blodig W (2001) Lignin peroxidase structure and function. Biochem Soc Trans 29(2):111-116

Pivarnik LF, Senegal AG, Rand AG (1995) Hydrolytic and transgalactosil activities of commercial $\beta$-galactosidase (lactase) in food processing. Adv Food Nutr Res N Y 38:1-102

Qureshi MA, Khare AK, Pervez A (2015) Enzymes used in dairy industries. Int J Appl Res 1(10):523-527 
Raj J, Prasad S, Bhalla TC (2006) Rhodococcus rhodochrous PA-34: a potential biocatalyst for acrylamide synthesis. Process Biochem 41:1359-1363

Raju AA, Chandrababu NK, Rose C et al (1996) Eco-friendly enzymatic dehairing using extracellular proteases from a bacillus species isolate. J Am Leather Chem Assoc 91:115-119

Rao MB, Tanksale AM, Ghatge MS et al (1998) Molecular and biotechnological aspects of microbial proteases. Microbiol Mol Biol Rev 62(3):597-635

Riffaldi R, Levi-Minzi R, Cardelli R et al (2006) Soil biological activities in monitoring the bioremediation of diesel oilcontaminated soil. Water Air Soil Pollut 170:3-15

Rossa PN, De Sa EMF, Burin VM et al (2011) Optimization of microbial transglutaminase activity in ice cream using response surface methodology. Lwt Food Sci Technol 44:29-34

Rubilar O, Diez MC, Gianfreda L (2008) Transformation of chlorinated phenolic compounds by white rot fungi. Crit Rev Environ Sci Technol 38:227-268

Sabu A (2003) Sources, properties and applications of microbial therapeutic enzymes. Indian J Biotechnol 2:234-241

Sankaran S (1995) Five decades of leather: a journey down memory lane. Indian Leather, Madras

Sarkissian CN, Shao Z, Blain F et al (1999) A different approach to treatment of phenylketonuria: phenylalanine degradation with recombinant phenylalanine ammonia lyase. Proc Natl Acad Sci USA 96:2339-2344

Saxena RK, Ghosh PK, Gupta R et al (1999) Microbial lipases: potential biocatalysts for the future industry. Curr Sci 77:101-115

Schafer T, Kirk O, Borchert TV et al (2002) Enzymes for technical applications. In: Fahnestock SR, Steinbüchel A (eds) Biopolymers. Wiley-VCH, Cambridge, pp 377-437

Schmid A, Dordick JS, Hauer B et al (2001) Industrial biocatalysis today and tomorrow. Nature 409:258-268

Sharma R, Chisti Y, Banerjee UC (2001) Production, purification, characterization and applications of lipases. Biotechnol Adv 19:627-662

Sivaramakrishnan S, Gangadharan D, Nampoothiri KM et al (2006) $\alpha$-Amylases from microbial sources-an overview on recent developments. Food Technol Biotechnol 44(2):173-184
Soares I, Tavora Z, Patera R et al (2012) Microorganism-produced enzymes in the food industry. In: Valdez DB (ed) Food industry, scientific, health and social aspects of the food industry, pp 83-94. doi:10.5772/31256

Srivastava N, Singh P (2015) Degradation of toxic pollutants from pulp \& paper mill effluent. Discovery 40(183):221-227

Sumi H et al (1987) A novel fibrinolytic enzyme (nattokinase) in the vegetable cheese Natto; a typical and popular soybean food in the Japanese diet. Experientia 43:1110-1111

Thadathil N, Velappan SP (2014) Recent developments in chitosanase research and its biotechnological applications: a review. Food Chem 150:392-399. doi:10.1016/j.foodchem.2013.10.083

Treem WR, McAdams L, Stanford L et al (1999) Sacrosidase therapy for congenital sucrase-isomaltase deficiency. J Pediatr Gastroenterol Nutr 28:137-142

Ulery BD, Nair LS, Laurencin CT (2011) Biomedical applications of biodegradable polymers. J Polym Sci B Polym Phys 49(12):832-864

Vaillant F, Millan A, Dornier M et al (2001) Strategy for economical optimization of the clarification of pulpy fruit juices using crossflow microfiltration. J Food Eng 48:83-90

Vellard M (2003) The enzyme as drug: application of enzymes as pharmaceuticals. Curr Opin Biotechnol 14:444-450

Vroman I, Tighzert L (2009) Biodegradable Polymers. Materials 2:307-344

Walsh GA, Power RF, Headon DR (1993) Enzymes in the animalfeed industry. Trends Biotechnol 11(10):424-430. http://www. sebi.gov.in/cms/sebi_data/attachdocs/1453372309087.pdf

Yadav S, Yadav PK, Yadav D et al (2001) Pectin lyase: a review. Process Biochem 44(1):1-10

Zaidi KU, Ali AS, Ali SA et al (2014) Microbial tyrosinases: promising enzymes for pharmaceutical, food bioprocessing, and environmental industry. Biochem Res Int. doi:10.1155/2014/ 854687

Zaks A (2001) Industrial biocatalysis. Curr Opin Chem Biol $5(2): 130-136$

Zhang H, Sang Q, Zhang W (2012) Statistical optimization of chitosanase production by Aspergillus sp. QD-2 in submerged fermentation. Ann Microbiol 62(1):193-201 